\title{
PERBEDAAN KETERAMPILAN BERPIKIR KRITIS SISWA YANG BERBANTUAN MEDIA AUDIO VISUAL DAN LKS CETAK SEBAGAI PANDUAN PERCOBAAN PADA METODE EKSPERIMEN DENGAN PENDEKATAN VERIFIKASI KELAS XI SMA NEGERI 1 SEWON
}

\author{
Suryandari ${ }^{1}$, Nur Kadarisman ${ }^{2}$, Joko Sudomo ${ }^{3}$ \\ Pendidikan Fisika, Universitas Negeri Yoygakarta \\ Email:suryandari.ayie@gmail.com
}

\begin{abstract}
The researched purpose to know the differences of student critical thinking skills, along with knowing where was the better group between audio visual media and paper sheet in student critical thinking as experiment guidelines. This research was a quasi-experiment with the static pretest posttest group design. The populate was belonged to all student of XI IPA. The sample was given by cluster random sampling, and the result is XI IPA 1 as the group help by audio visual media, XI IPA 5 as paper sheet. The instruments were 10 questions of critical thinking skill and psychomotor observation sheet. Data were obtained from posttest and psychomotor observation scores. Data analyzing used independent sample T-test and different populate average estimation test. The results showed that there were differences of student critical thinking skills between of the group that helped by audio visual media and paper sheet, along with the student critical thinking skills of audio visual media group are better than paper sheet.
\end{abstract}

Key Words: experiment method; cognitive critical thinking skill; psychomotor; audio visual media; paper sheet

\begin{abstract}
ABSTRAK
Penelitian ini bertujuan untuk mengetahui adanya perbedaan keterampilan berpikir kritis siswa, serta mengetahui manakah keterampilan berpikir kritis siswa yang lebih baik pada pembelajaran eksperimen dengan metode verifikasi antara kelompok yang berbantuan media audio visual dan LKS cetak sebagai panduan percobaan. Penelitian ini adalah kuasieksperimen dengan model pretest and posttest experimental group design. Populasi dalam penelitian ini adalah seluruh siswa kelas XI IPA. Sampel ditentukan dengan teknik cluster random sampling dengan sampel adalah XI IPA 1 sebagai kelompok yang berbantuan media audio visual dan XI IPA 5 yang berbantuan LKS cetak. Instumen dalam penelitian ini yakni 10 butir soal keterampilan berpikir kritis siswa dan lembar observasi psikomotorik. Pengumpulan data penelitian didapat dari nilai posttest dan lembar observasi keterampilan psikomotorik siswa pada kedua kelas penelitian. Adapun metode yang digunakan untuk menganalisis data adalah dengan independent sample T-test dan uji pendugaan beda ratarata populasi. Hasil penelitian menunjukkan terdapat perbedaan keterampilan berpikir kritis siswa antara kelompok yang berbantuan media audio visual dan LKS cetak sebagai panduan percobaan pada metode eksperimen dengan pendekatan verifikasi, perbedaan, serta keterampilan berpikir kritis siswa pada kelompok yang berbantuan media audio visual lebih baik daripada yang berbantuan LKS cetak.
\end{abstract}

Kata Kunci: metode eksperimen; keterampilan berpikir kritis ranah kognitif; keterampilan psikomotorik; media audio visual; LKS cetak. 


\section{PENDAHULUAN}

Berdasarkan observasi peneliti selama KKN-PPL di SMA N 1 Sewon, proses pembelajaran yang dilakukan khusunya kegiatan belajar mengajar fisika, cenderung bersifat konvensional, sehingga siswa menjadi pasif dan merasa jenuh. Dalam kegiatan pembelajaran, kegiatan praktikum dilakukan secara terpisah dengan kegiatan pembelajaran. Metode eksperimen cenderung digunakan hnya ketika siswa akan menghadapi ujian praktik. Mengingat kondisi tersebut, tidak mengherankan jika guru lebih memilih. Selain itu, proses belajar fisika menggunakan strategi team teaching. Dalam hal ini berdampak terhadap kurangnya keterampilan berpikir kritis siswa. Disisi lain, Glaser mendefinisikan berpikir kritis sebagai (Alec Fisher, 2009:3) : (1)Suatu sikap mau berpikir secara mendalam tentang masalah-masalah dan hal- hal yang berada dalam jangkauan pengalaman seseorang; (2) pengetahuan tentang metode-metode pemeriksaan dan penalaran yang logis; dan (3) semacam suatu keterampilan untuk menerapkan metode-metode tersebut. berpikir kritis menuntut upaya keras untuk memeriksa setiap keyakinan atau pengetahuan asumtif berdasarkan bukti pendukungnya dan kesimpulankesimpulan lanjutan yang diakibatkannya.

Berpikir kritis dengan jelas menuntut interprestasi dan evaluasi terhadap observasi, komunikasi, dan sumbersumber informasi lainnya. Suatu bentuk observasi, komunikasi dan aktivitas terampil yang dapat diwujudkan dalam proses belajar mengajar fisika adalah dengan menggunakan metode eksperimen. Saat siswa bereksperimen, siswa akan secara langsung mengalami suatu proses observasi terhadap eksperimennya, kemudian saling berkomunikasi dengan kelompoknya sehingga siswa dapat terampil dalam melakukan eksperimennya.

Selain itu, dalam menanamkan pemahaman konsep khususnya, seorang guru juga membutuhkan media pembelajaran. Salah satu alternatifnya adalah media audio visual. Media audiovisual dipilih karena memiliki kelebihan dalam membantu menyampaikan materi pelajaran dimana siswa seolah melihat langsung fenomena fisika tanpa harus pergi ke lapangan. Banyak ahli berpendapat, bahwa $75 \%$ dari pengetahuan manusia sampai ke otaknya melalui mata dan selebihnya melalui pendengaran dan indera lainnya

Berdasarkan latar belakang tersebut maka diajukan beberapa rumusan masalah, yaitu:

1. Apakah ada perbedaan keterampilan berpikir kritis ranah kognitif dan keterampilan psikomotorik siswa antarakelompok yang berbantuan me dia audio visual dan LKS cetak sebagai panduan percobaan?

2. Manakah yang lebih baik keterampilan berpikir kritis ranah kognitif dan keterampilan psikomotorik siswa antara kelompok yang berbantuan media audio visual dan LKS cetak sebagai panduan percobaan?

\section{METODE PENELITIAN}

Penelitian ini menggunakan dua kelas, yaitu kelas pertama berbantuan media audio visual dan kelas berbantuan LKS cetak. Dalam penelitian ini digunakan pretest dan posttest. Desain eksperimen penelitian ini, yaitu Static Pretest Posttest Group Design. Berikut diagram pelaksanaan penelitian : 


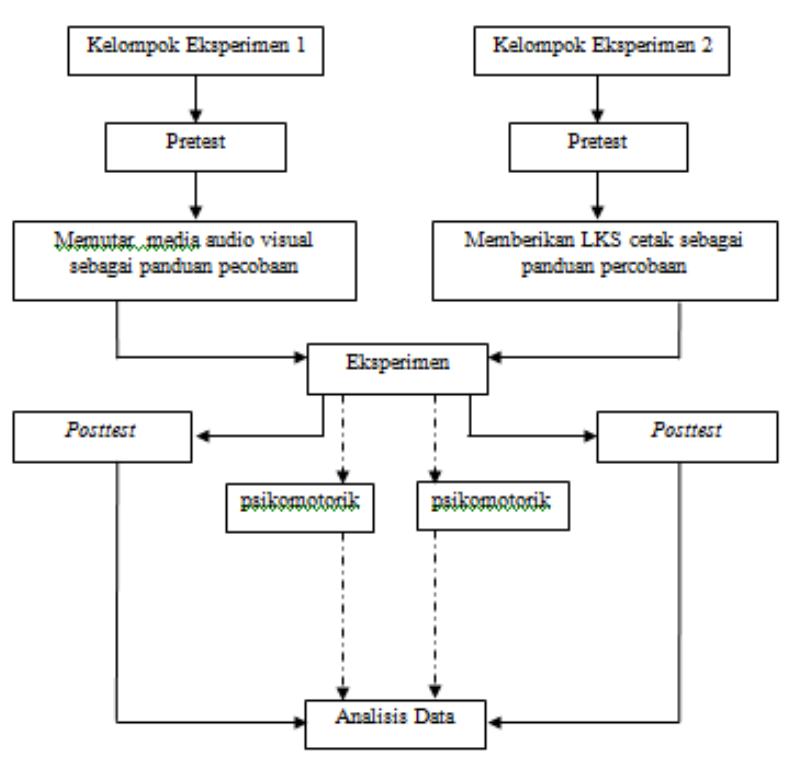

Gambar 1. Pelaksanaan Penelitian

Data hasil pengambilan data akan dianalisis menggunakan Independent Sample T-test dan Uji pendugaan beda nilai rata-rata populasi.

\section{HASIL DAN PEMBAHASAN}

Hasil penelitian menunjukkan bahwa (1) ada perbedaan keterampilan berpikir kritis ranah kognitif dan psikomotorik siswa antara kelompok yang berbantuan media audio visual dan LKS cetak serta (2) keterampilan keduanya lebih baik pada kelompok yang berbantuan media audio visual. Hal ini dapat ditunjukkan dengan beberapa hal, yaitu

Tabel 1 Kemampuan Akhir

\begin{tabular}{|l|c|c|}
\hline \multirow{2}{*}{} & \multicolumn{2}{|c|}{ Kemampuan Akhir } \\
\cline { 2 - 3 } & KE1 & KE2 \\
\hline Jumlah siswa & 27 & 27 \\
\hline Rerata & 76.53 & 71.85 \\
\hline Nilai Tertinggi & 88.4 & 89 \\
\hline Esiswa tuntas & 25 & 12 \\
\hline \% ketuntasan & $92,5 \%$ & $44 \%$ \\
\hline & \multicolumn{2}{|c|}{ Psikomotorik } \\
\hline Rerata & 36.62 & 26.3 \\
\hline
\end{tabular}

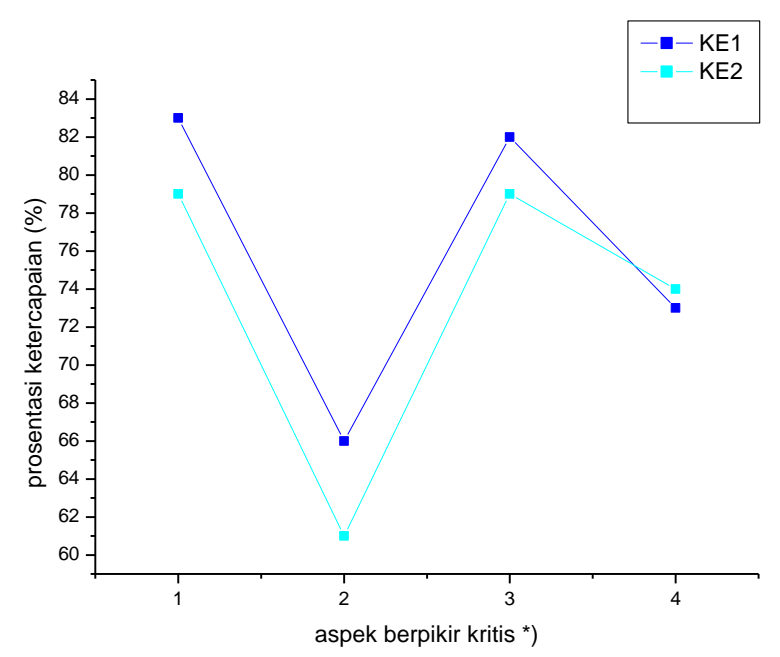

Gambar 2. Grafik Distribusi Berpikir Kritis

Berdasarkan tabel 1 dan gambar 2 dapat disimpulkan bahwa pada kelompok yang berbantuan media audio visual memiliki keterampilan berpikir kritis yang lebih baik selain karena nilai rata-rata dan presentase siswa lebih tinggi, tetapi juga distribusi aspek berpikir kritis pada kelompok yang berbantuan media audio visual berada pada zona dan rentang lebih tinggi.

Analisis diperkuat dengan hasil uji statistik menggunakan Independent sample T-test dan pendugaan nilai rata-rata populasi, pada tabel 2 berikut ini :

Tabel 2 Nilai Uji Hipotesis Tiap Ranah

\begin{tabular}{|c|c|c|}
\hline \multirow{2}{*}{} & \multicolumn{2}{|c|}{ Uji Hipotesis } \\
\cline { 2 - 3 } & Aspek Kognitif & $\begin{array}{c}\text { Keterampilan } \\
\text { Psikomotorik }\end{array}$ \\
\hline \multirow{2}{*}{$(p)$} & 0,044 & 0,038 \\
\hline$t_{\text {hitung }}$ & 2,064 & 2,135 \\
\hline \multirow{2}{*}{$t_{\text {tabel }}$} & 2,0057 & 2,0057 \\
\hline \multirow{2}{*}{} & Uji Pendugaan Beda NIlai Rata- rata \\
\cline { 2 - 3 } & Aspek Kognitif & $\begin{array}{c}\text { Keterampilan } \\
\text { Psikomotorik }\end{array}$ \\
\hline \multirow{2}{*}{$0,1246<\mu_{1}-\mu_{2}<$} & $\begin{array}{c}7,752<\mu_{1}-\mu_{2}< \\
12,906\end{array}$ \\
\end{tabular}




\section{PENUTUP}

Berdasarkan pembahasan tersebut, maka disimpulkan bahwa ada perbedaan keterampilan berpikir kritis siswa pada ranah kognitif dan psikomotorik siswa antara kelompok yang berbantuan media audio visual dan LKS cetak sebagai panduan percobaan. Selain itu, keterampilan berpikir kritis siswa pada ranah kognitif dan psikomotorik siswa pada kelompok yang berbantuan media audio visual lebih baik daripada LKS cetak sebagai panduan percobaan. Penelitian juga dapat dilakukan dari ranah lainnya, yaitu afektif

\section{DAFTAR PUSTAKA}

Alec Fisher. (2003). Berpikir Kritis Sebuah Pengantar. Jakarta : Erlangga

Amir Hamzah Suleiman. (1985). Media Audio Visual untuk Pengajaran, Penerangan, dan Penyuluhan. Jakarta : Gramedia.

Azhar Arsyad. (2009). Media Pembelajaran. Jakarta : PT. Raja Grafindo Persada.

Javandalasta, Panca. (2011). 5 Hari Mahir Bikin Film. Surabaya: Mumtaz Media.

Maksum (2012). Taksonomi Bloom Revisi. Cirebon : IAIN Syekh Nurjati (Rektor IAIN Syekh Nurjati)

Nana Sudjana. (2002). Metode Statistika. Bandung: Tarsito

Prastowo, Andi. (2012). Panduan Kreatif Membuat Bahan Ajar Inovatif. Yogyakarta: Diva Press.

Rusyna, Adun. (2014). Keterampilan Berpikir. Yogyakarta: Ombak.

Sani, Asrul. (2013). Naskah Non Berita: Dokumenter. Yogyakarta: Mercu Buana Press

Smaldino, Sharon E.,dkk. (2011). Instructional Tecknology and Media for Learning-Teknologi Pembelajaran dan Media untuk Belajar. Jakarta: Kencana

Sugiyono. (2010). Statistika Untuk Penelitian. Bandung : Alfabeta
(2017). Metode Penelitian Kualitatif (Untuk Penelitian yang Bersifat: Eksploratif, Enterpretif, Interaktif dan Konstruktif). Bandung: Alfabeta Press.

Surasa, Nisa Nuraini, dkk. (2017). Proses Belajar Siswa Dalam Meningkatkan Kemampuan Berpikir Kritis Mata Pelajaran Ekonomi SMA. Semarang. Jurnal Pendidikan. Universitas Negeri Malang.

Triton P B. (2006). SPSS 16.0 Terapan Riset Statistik Parametrik. Yogyakarta : Penerbit Andi Yogyakarta

Triyani. (2012). Perbedaan Hasil Belajar Fisika Antara Penggunaan Video Sebagai Panduan Percobaan Dengan Penggunaan Lks Sebagai Panduan Percobaan Pokok Bahasan Gerak Harmonik Sederhana Pada Benda Elastik Di Sma N 11 Yogyakarta. Laporan Penelitan . UNY

Vika Agustin M. (2011). Perbedaan Hasil Belajar Fisika Materi Suhu dan Kalor Antara Kelompok Yang Menggunakan Metode Eksperimen Berbantuan Media Audiovisual Dengan Kelompok Yang Menggunakan Metode Eksperimen Berbantuan Media Cetak. Laporan Penelitan . UNY

Wiwit Nali T. (2012). Keefektifan Kerja Laboratorium Fisika Dengan Pendekatan Induktif Dan Deduktif Terhadap Sikap Ilmiah Dan Keterampilan Berpikir Kritis Siswa SMA. Laporan Penelitian. Yogyakarta : UNY. 